\title{
IN REFERENCE TO PHONATION LARYNX FIXATION: COMPUTER GRAPHIC RECORD
}

\author{
Hana Sochorováa ${ }^{a}$ Josef Pešák ${ }^{\mathrm{b}}$, Stanislav Laichmanº, Michal Grepl ${ }^{\mathrm{b}}$
}

\author{
a Department of Medical Examination Methods and Medical Biology, University of Ostrava, Syllabova 19, Ostrava 3, \\ Czech Republic \\ ${ }^{b}$ Department of Biophysics \\ c Department of Normal Anatomy, Faculty of Medicine, Palacký University, Hněvotínská 3, 77515 Olomouc, Czech \\ Republic
}

Received: May 20, 2003; Accepted in revised form June 30, 2003

Key words: Vocal apparatus / Larynx / Modal voice / Falsetto voice / Phonation larynx fixation

The vocal apparatus serves phonation. It represents a biocybernetic self-regulating system, disposing of a feedback network of the central nervous system. The larynx is a self-induced vibrating system. The larynx, functioning as the phonation apparatus of the vocal apparatus, is a source of human voice. In every individual its frequency range corresponds to about eight semitones in speech and about two octaves of the so-called chest register in singing, denoted also as a thoracic or modal voice. This is followed by one more octave of the so-called cranial register or falsetto voice. We were interested in changes of the larynx positions at intonation in the fundamental singing registers, both modal and falsetto, in professional male singers. At our disposal were 11 professional male singers. We investigated changes in the position of the laryngeal structures simultaneously with the aid of an X-ray apparatus, the acoustic and mechanical signals registered by means of the B \& K 4369 acceleration recorder. It has been found that at phonation with the modal voice a change in the position of the laryngeal structures takes place in two different ways, whereas the larynx movements at falsetto remain the same. It has been suggested that a complex fixation apparatus participates in the phonation larynx movements. Of the same complex character are also the problems connected with the examination of the entire vocal apparatus. For the purpose of compiling the present pieces of knowledge in the field of human voice studies, we have made the most advantageous use of the presently most complex system Authorware for the production of some interactive multimedial programmes on personal computers.

\section{INTRODUCTION}

The vocal apparatus serves phonation ${ }^{1,2}$. Belonging to this apparatus are parts of the cranial sections of the digestive tract (oral cavity) and the respiratory tract (nasal cavity and accessory cavities, larynx, trachea with bronchi, and lungs). The vocal apparatus represents a biocybernetic self-regulating system ${ }^{3}$, disposing with a feedback network of the central nervous system. The larynx is a self-induced vibrating system ${ }^{4,5}$. It is closely connected with the supra-laryngeal tract as a secondary sound radiator functioning as a resonator ${ }^{6}$.

The so-called fixation larynx apparatus ${ }^{7}$ plays an essential role as a functional muscle group, a functional motor mechanism, dynamics of its actions being controlled reflexively and, in most cases, subconsciously. Belonging to it are three classical groups of the laryngeal muscles (anterior, posterior, and lateral) ${ }^{8}$, controlling directly setting up of the height of the fundamental vocal-chord frequency F0. Six muscle groups, see Fig. 1, then control the position of the larynx $\mathrm{x}^{9,10}$. Belonging to the fixation apparatus is also the base of the cranial skeleton and the cranial vertebrae of the spinal column.

The larynx, functioning as the phonation apparatus of the vocal apparatus, is the source of the human voice. In every individual its frequency range corresponds to about eight semitones in speech and about two octaves of the so-called chest register in singing, denoted also as a thoracic or modal voice. Following it is about one more octave of the so-called cranial register or falsetto voice. Denoted by the term register is a series of tones having the same acoustic properties ${ }^{11,12}$. The modal and falsetto voices are differentiated by their qualities. The modal voice is richer and more colourful, the falsetto one being less colourful. In the modal voice, the vocalchord fringes are free and strengthened; in the falsetto voice, on the other hand, they are attenuated, their fringes being formed directly by the ligaments, the real vocal chords. Appearing on the boundary between the modal and falsetto registers is a group of so-called amphoteric tones. Because of their identical frequencies they may be produced by both the modal and falsetto voices, or by mixture of both. 


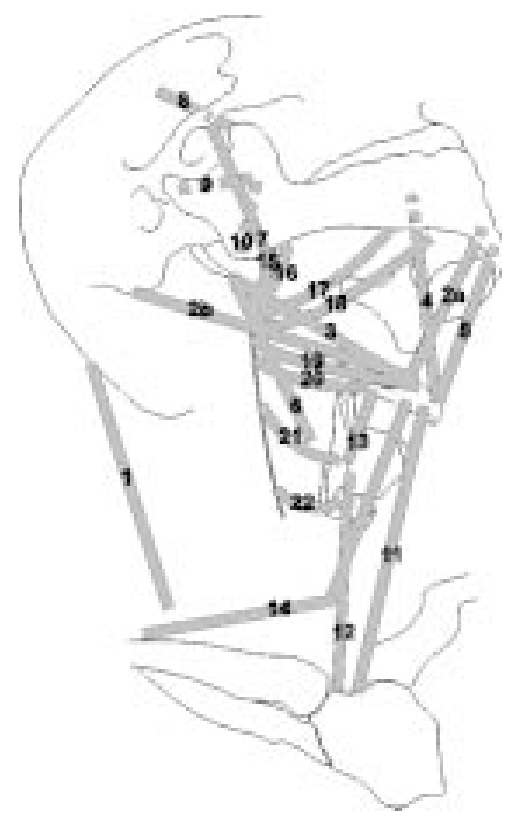

Fig. 1. A diagrammatic representation [10] of the muscle groups I-VI of the fixation larynx apparatus. I. 1. m. splenius capitis; II. 11. m. sternohyoideus, 12. m. sternothyroideus, 14. m. omohyoideus; III. 2a. m. digastricus ventr. anter., 4. mylohyoideus, 5. m. geniohyoideus, 13. m. thyroideus; IV. 7. m. masseter, 8. m. temporalis, 9. m. pterygoideus lat., 10. m. pterygoideus med.; V. 2. b. m. digastricus ventr. post., 3. stylohyoideus, 6 . m. stylopharyngeus, $15 . \mathrm{m}$. constrictor pharingis sup. pars pterygopharyngea, $16 . \mathrm{m}$. constrictor pharyngis sup. pars buccopharyngea, $17 . \mathrm{m}$. constrictor pharingis sup. pars mylopharyngea, $18 . \mathrm{m}$. constrictor pharyngis sup. pars glossopharyngea, 19. m. constrictor pharyngis medius pars chondropharyngea, 20. m. constrictor pharyngis medus pars ceratopharyngea, $21 . \mathrm{m}$. constrictor pharyngis inferior pars thyropharyngea; VI. 22. m. constrictor pharyngis inferior pars cricopharyngea.

We were interested in changes in the larynx positions at intonation in the fundamental singing registers, both modal and falsetto, in professional male singers.

\section{MATERIALS AND METHODS}

At our disposal there were 11 professional male singers ( 8 members of the Moravian Theatre in Olomouc, 3 members of the Singing Choir of the Pedagogicae Faculty, Palacký University in Olomouc). In all of them we registered their singing range, voice range, the chosen tone for measuring by the modal and falsetto voices, and the duration of their professional careers.

We investigated changes in the position of the laryngeal structures ${ }^{13-15}$ simultaneously with the aid of an $\mathrm{X}$-ray apparatus ${ }^{16,17}$, the acoustic and mechanical signals were registered by means of the B \& K 4369 accele- ration recorder; see diagramatic illustration in Fig. 2. Fig. 3 shows a subject under investigation holding the acceleration recorder in his hand, so that the collar of the recorder does not screen the X-rays.

Measuring was carried out directly at the Chiralux 2 X-ray apparatus, the X-ray lamp of $30 \mathrm{~kW}$ output being used in the small focus regime, mode $1.2 \times 1.2 \mathrm{~mm}$, 44-48 kV voltage, $240 \mathrm{~mA}$ current, $0.1 \mathrm{~s}$ exposure time, $24 \mathrm{mAs}$ exposure value being set with respect to the visualization of the larynx.

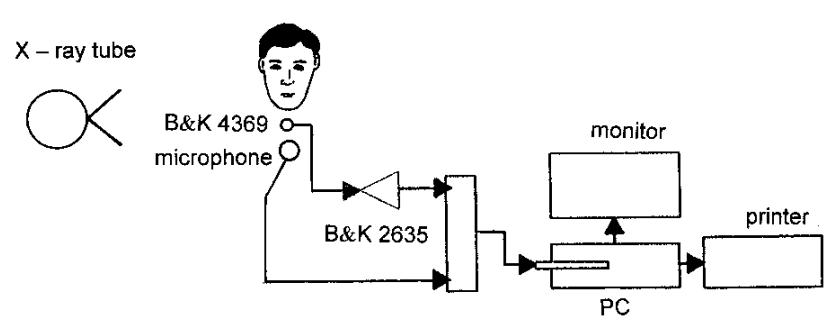

Fig. 2. Combined measuring apparatus for the simultaneous recording of X-ray photographs, both the mechanical signal from the thyroid cartilage surface and the acoustic signal in the production of the human voice.

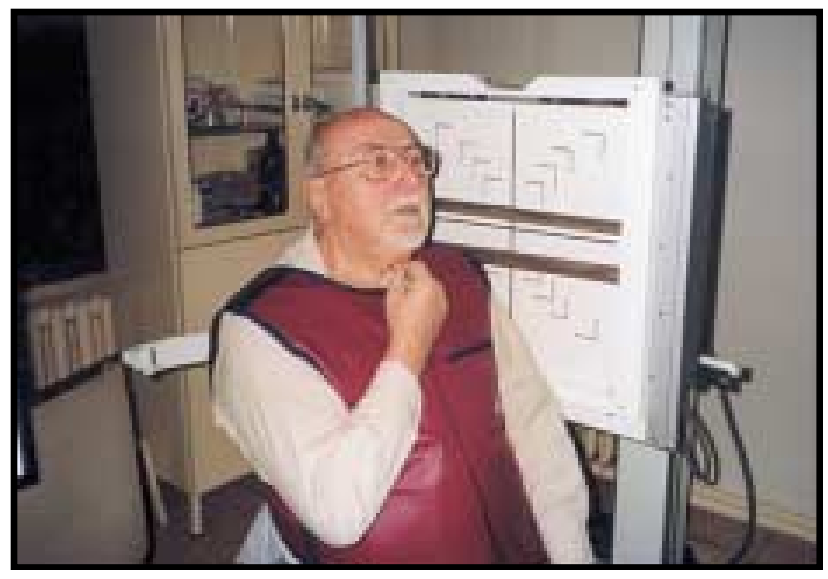

Fig. 3. A photograph showing an examined person wearing a protective aoron and holding the acceleration recorder. The AKG C 10005 microphone with the MZ-R3 mini-disc was located approx. $1 \mathrm{~m}$ from the person. The recording device did not include a secondary diaphragm and the focus - camera distance was about $1.2 \mathrm{~m}$.

\section{MEASURING}

In each subject under investigation a series of snaps were taken during expiration and with phonation of the same amphoteric modal and falsetto tones. When taking one X-ray snap, the radiation load was equal to $0.03 \mu \mathrm{Gy} \sim 1.7 \times 10^{-6}$ of the annual tolerance dose.

Note: In accordance with the Notice No. 184 of the Atomic Act of the State Bureau for Nuclear Safety, the annual radiation load allowance is $50 \mathrm{mGy}$. 


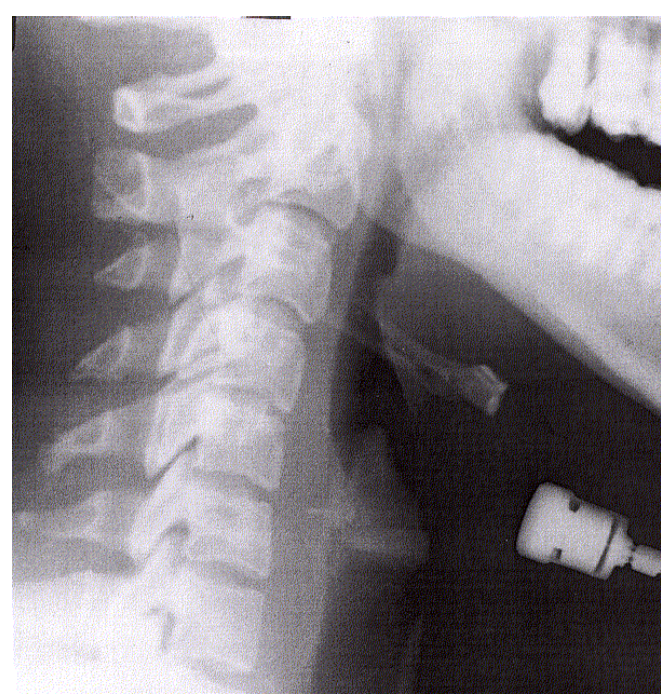

Fig. 4. The larynx position with module voice phonation. $(329.6 \mathrm{~Hz})$. The outline of the acceleration recorder can be seen under the mandible.

42 X-ray snaps in total were taken. In these snaps, easily comparable and well recognisable identification points were found, e.g., those displaying explicit ossification. These were then transferred on to a translucent foil in a single projection. From network imaging produced, the individual positions of the cervical vertebrae, the mandible, tongue bone and cartilaginous skeleton of the larynx were measured. The same imaging was compared electronically with the aid of the Scion Image programme with 200 dpi resolution; see Fig. 4.

The recording of the acoustic and mechanical signals was evaluated using the Sound Forge and Mirocal Origin programmes followed by the fast Fourier analysis FFT. From the FFT results, acoustic differences of the modal (Fig. 4 - left) and falseto (Fig. 4 - right) spectra of the corresponding amphoteric tones could be compared. In the modal voice both the 2nd and 3rd harmonic component was not present in the spectrum.

\section{RESULTS}

Two subjects under investigation were excluded because of the inability to phonate with the falsetto voice at unchanged positions of the larynx. Under simultaneous examination of the acoustic spectra, the remaining 9 subjects - professional male singers - were divided into two groups according to the identical larynx positions. In both groups the distances between the hyoid bone and the thyroid cartilage decrease, the larynx becomes tilted, and the cranial line of the cervical vertebrae $\left(c_{1}-c_{6}\right)$ is ventrally bent in an imaginary vertical axis in the falsetto voice. In the first group (see Fig. 6), in comparison with the expiration position, the position of the hyoid bone lowers ad tilts in the modal voice, whereas
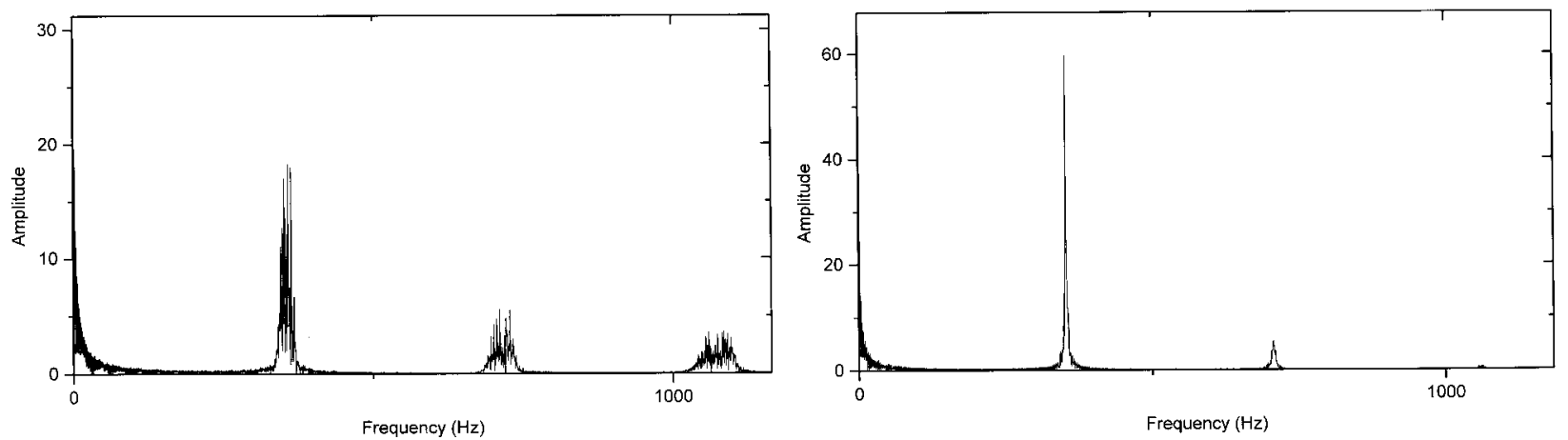

Fig. 5. Harmonic spectrum with modal voice (left), and with in falsetto voice (right). The $x$ - axis shows frequency $(\mathrm{Hz})$, the $\mathrm{y}-$ axis shows amplitude $(\mathrm{mV})$ of the harmonic components.

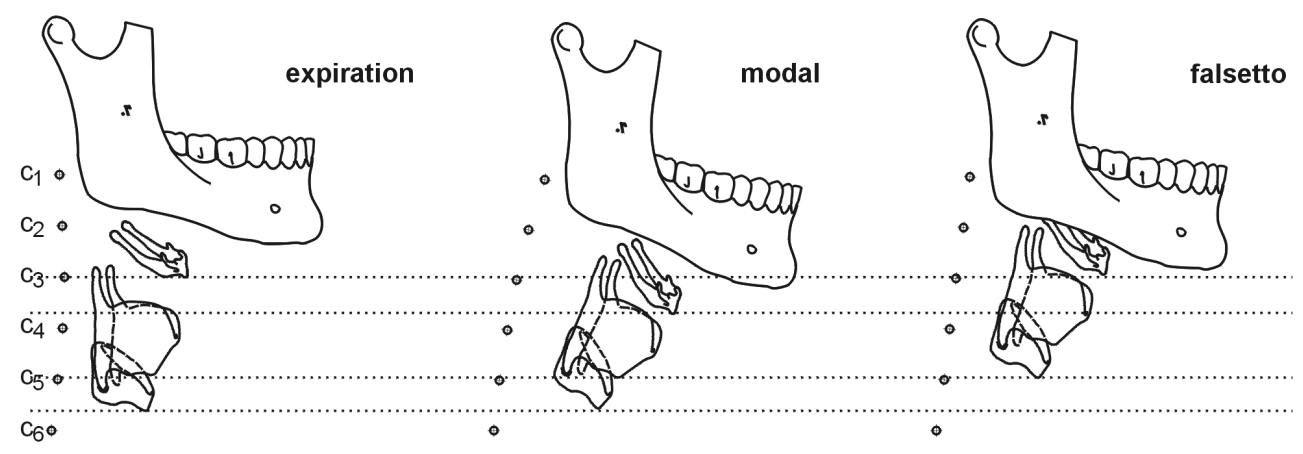

Fig. 6. First group (see text), 2 probands. 


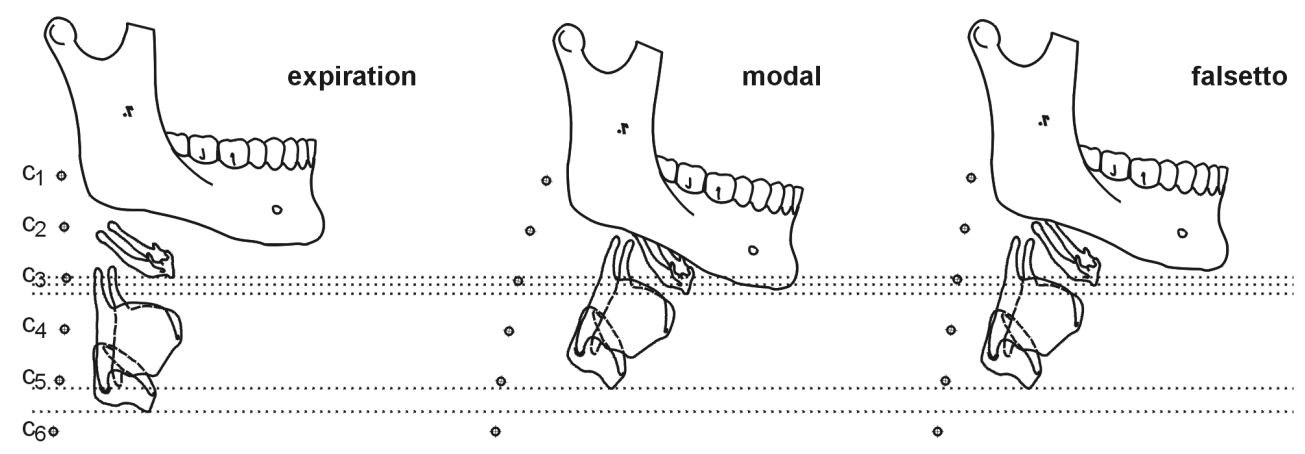

Fig. 7. The second group (see text), 7 subjects. The three upper lines pass through the lowest part of the hyoid bone body, the lower line passes through the positions of the cricoid cartilage during expiration, with modul as well as falsetto phonation.

the positions of the cricoid cartilage as well as the thyroid cartilage together with the hyoid bone rise in the falsetto voice. In the second group (see Fig. 7), when phonating in both the modal and falsetto voices, the most conspicuous change in comparison with the expiratory position is rising of the position of the cricoid cartilage and the thyroid cartilage with the lowered position of the tongue bone.

\section{DISCUSSION}

The study was carried out with professional male singers only, because the subjects had been instructed with regard to the technique of production of the modal and falsetto registers and an auditory control was also possible.

The study was not evaluating female singers due to the fact that 4 of them created their amphoteric tones by mixing, which was probably brought about by their professional career. Pure modal and falsetto tones were no longer distinguished.

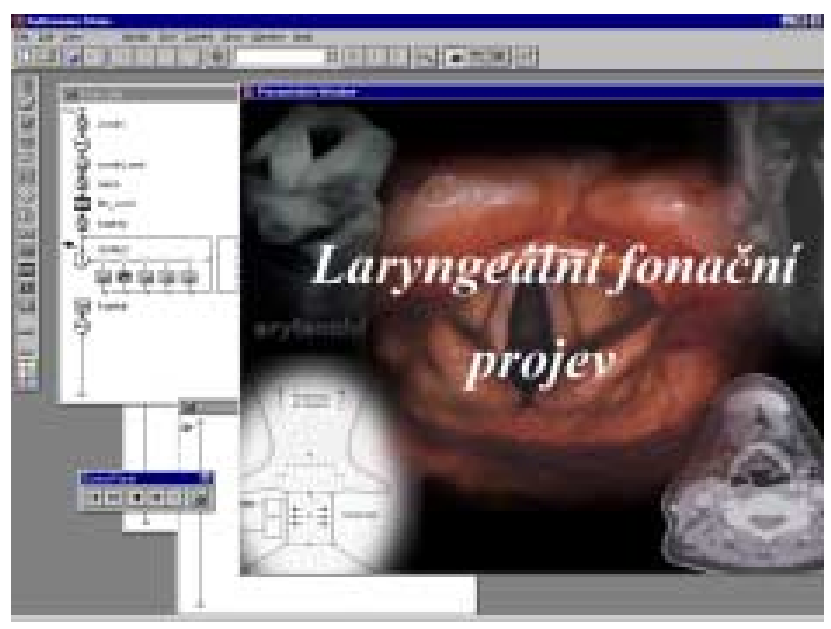

Fig. 8. The introductory screen showing the Laryngeal phonation expression of the project [18] for inserting externally prepared texts, slides, video graphs, etc.
The phonating larynx in professional as well as nonprofessional singers has been described by Fink and Damarest ${ }^{14}$. Their findings correspond with the behaviour manifestations of our second group.

\section{CONCLUSION}

We observed that with modal intonation, a change of the larynx structures position occurs in two different ways, whereas the larynx movements with falsetto intonation remain the same. The position of the tongue bone relative to the suspended larynx, i.e. to the cartilago thyroidea, then does not change.

We indicated that a complex fixation apparatus participates in the phonation larynx movements. Similarly, problems involved in a study of the whole vocal apparatus are very complicated as well. It is not possible to include them at their full extent into one separate study mainly because they also involve other scientific disciplines. Advantage was taken of the Autorware system, the most complex author system available for production of PC interactive multimedia programsavailable, to compile the up to date knowledge in the field of human voice studies ${ }^{15}$. Fig. 7 shows an introductory screen projection of inserting externally prepared texts, slides, video graphics etc.

\section{ACKNOWLEDGEMENT}

Prepared under the sponsorship of the research task CEZ:J14/98:N30000018 "Integrated study of voice and speech"

\section{REFERENCES}

1. Sochorová H, Pešák, J, Laichman S. K biofyzice vokálního ústrojí. In: Sborník přednášek 7. semináře univerzitního Společenství pro studium hlasu a řeči, Ed: Josef Pešák, ÚLB LF UP v Olomouci, Olomouc 2001.

2. Pešák J, Grézl T, Růžičková K. Vocal apparatus of human voice. Proceedings of international conference on Biomechanics of man 
2002, Ed: K. Jelen, S. Kušová, M. Chalupová, J. Otáhal, Charles University in Prague, Faculty of Physical Education and Sport in cooperation with Czech Society of Biomechanics, Prague 2002.

3. Pešák J. Vokální ústrojí: Biokybernetický autoregulační systém. In: Proceedings Interaction and Feedbacks' 2002, Ed: I. Zolotarev, Institute of Thermomechanics AS CR, Prague 2002.

4. Javorskij BM, Selezněv JA. Přehled elementární fyziky. SNTL, Praha 1989.

5. Pešák J, Grézl T, Grepl M, Jindra P. Fonační aparát vokálního ústrojí samobuzenou kmitající soustavou. In: Sborník 65. Akustického semináře, Ed: Ilona Bláhová, Ondřej Jiříček, Ediční středisko ČVUT v Praze, Praha 2002.

6. Pešák, J. Tvorba lidského hlasu I. a II. Pelikán, akademický bulletin UK 2. lékařské fakulty. Praha: Univerzita Karlova v Praze 2. lékařská fakulta, Vol. 10, 2002, č. 2 a 3, 10-13 and 7-11.

7. Grepl M, Pešák J. Fixační aparát hrtanu. In: Novinky ve foniatrii 2002, Ed: Olga Dlouhá, Milan Laštovka, Nakladatelství Galén, Praha 2002.

8. Borovanský L. Soustavná anatomie člověka, díl 1. a 2., Zdravotnické nakladatelství Avicenum, Praha 1976.

9. Sonninen Aatto A. The role of the external laryngeal muscles in length-adjustment of the vocal cords in singung. Academic dissertation, Medical Faculty of the University of Helsinki, Helsinki 1956.

10. Pešák J, Grepl M, Náhlá L, Vojtěchovský K, Laichman S. K hrtanovým strukturám při fonaci modálem a falzetem u stejného F0.
In: Sborník 60. Akustického semináře \& 36. Akustické konference, Ed: Ondřej Jiř́íček, Ediční středisko ČVUT v Praze, Praha 2000.

11. Bunch M. Dynamics of the singing voice. Springer-Verlag, Wien, New-York, Melbourne, 1993.

12. Titze IR. Principles of Voice Production. Prentice-Hall, Inc., London, Sydney, Toronto, Mexico, New Delhi, Tokyo, Singapore, Rio de Janeiro, 1994.

13. Fry DB. The Physics of Speech. Cambridge University Press, Cambridge, London, New York, Melbourne, 1979.

14. Fink BR \& Damarest RJ. Laryngeal Biomechanics. Harvard University Press, Cambridge, Massachusetts and London, England, 1878.

15. Palmer JM. Anatomy for Speech and Hearing. Wiliams \& Wilkins, Baltimore, Homg Kong, London, Munch, Philadelphia, Sydney, Singapore, Rio de Janeiro, Tokyo, 1993.

16. McAinisch TF. Physics in Medicine \& Biology Encyclopedia, Pergamon Press Ltd., Oxford, New York, Toronto, Sydney, Frankfurt, 1986.

17. Grepl M, Pešák J, Vojtěchovský K. Změny polohy hrtanu při intonaci. In: Sborník přednášek 8 . semináře unverzitního Společenství pro studium hlasu a řeči, Ed: Josef Pešák, ÚLB LF UP v Olomouci, Olomouc 2002.

18. Sochorová $\mathrm{H}$. Vývojově-výzkumný a výukový příspěvek k zobrazování laryngeálního fonačního projevu. Thesis, LF UP v Olomouci, Olomouc, 2003 